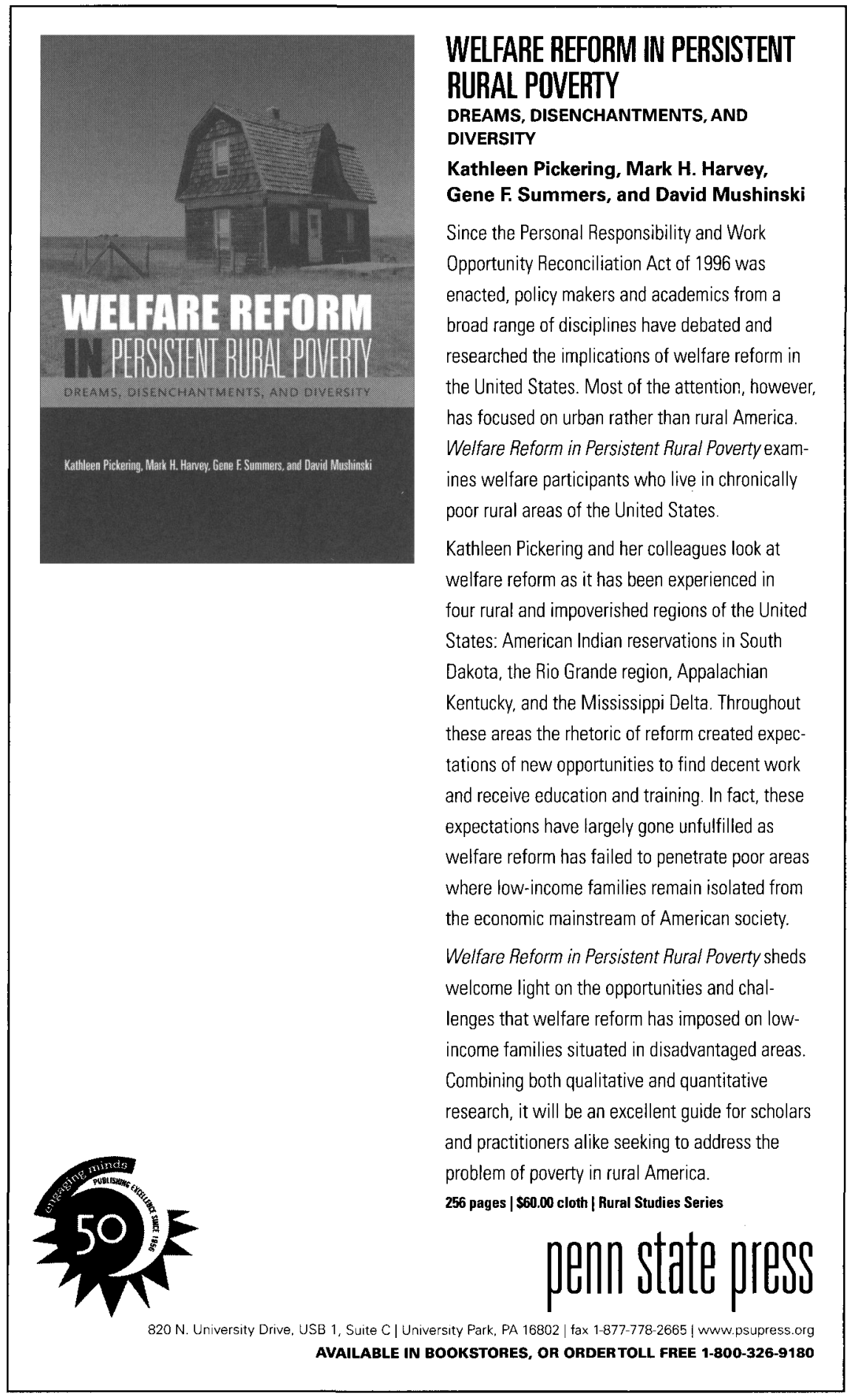




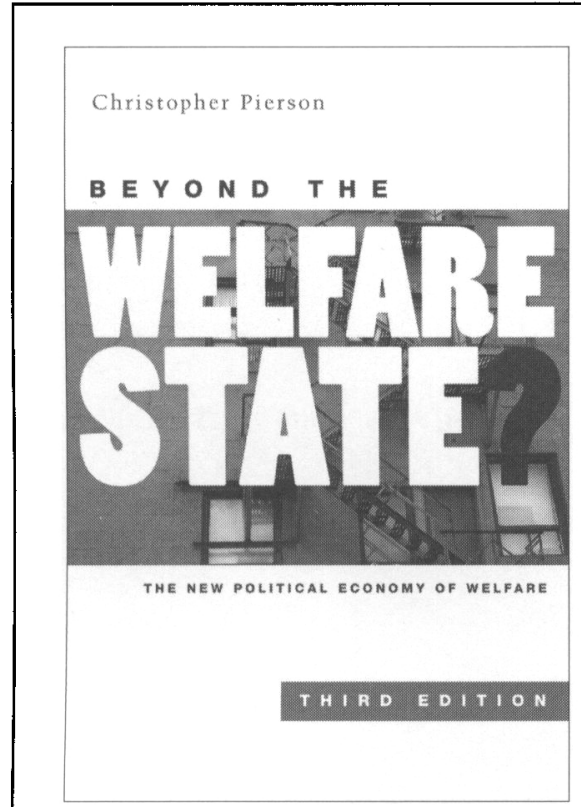

"Combining a detailed multicountry historical overview with a theoretical summary that is essential reading for anyone wishing to understand the real 'state' of the modern welfare state, Beyond the

Welfare State? is a tour de force of comparative analysis." -Mark Blyth, The Johns Hopkins University

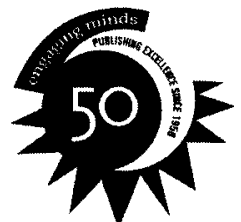

\section{BEYOND THE WELFARE STATE?}

THE NEW POLITICAL ECONOMY OF WELFARE THIRD EDITION

\section{Christopher Pierson}

Co-published with Polity Press

Over the past decade, Beyond the Welfare State? has become established as the key text on the emergence and development of welfare states. It offers a comprehensive and remarkably wellinformed introduction to the ever more intense debates that surround the history and, still more importantly, the future of welfare in advanced industrialized states.

Comprehensively revised and re-written, the third edition of the book embraces all of the most important theoretical and empirical developments in welfare state studies of recent years. Working within an explicitly comparative framework, the book draws on a wealth of international evidence to survey what are now the most pressing issues surrounding the future of welfare: among them, globalization, demographic change, declining fertility, postindustrialism and immigration. It draws extensively on the explosion of work on welfare states that has emerged within the North American political science community over the past ten years as well as giving detailed attention to developments with the UK, continental and northern

Europe, and beyond.

The third edition of Beyond the Welfare State? remains the most comprehensive and up-to-date guide to the complex of issues that surround welfare reform. It will be required reading for anyone who wants to come to terms with what is really at stake in arguments about the future of welfare.

\section{0 pages | $\$ 28.00$ paper}

Available in the U.S. and Canada

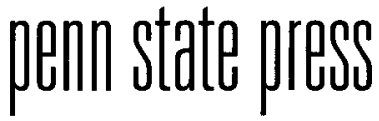

820 N. University Drive, USB 1, Suite C | University Park, PA 16802 | fax 1-877-778-2665 | www.psupress.org AVAILABLE IN BOOKSTORES, OR ORDER TOLL FREE 1-800-326-9180 


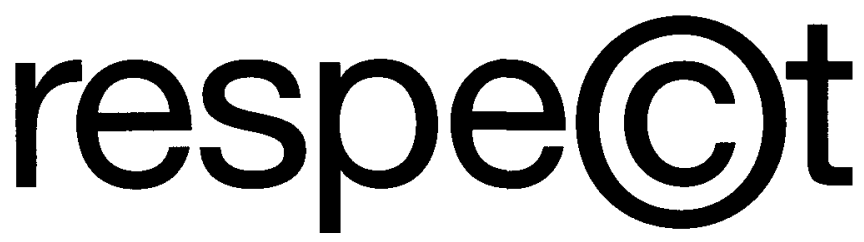

Don't dis copyright. Do the right thing - make sure you have permission before you use and share information. To learn more, contact the publisher or visit www.copyright.com.

(C) Copyright Clearance Center 


\section{Forthcoming Articles}

Kathleen Ferraiolo (James Mason University), "From Killer Weed to Popular Medicine: The Evolution of American Drug Control Policy, 1937-2000"

\section{Special Issues}

Jim Mohr (University of Oregon), "Health Policy in America" (Winter 2007) 


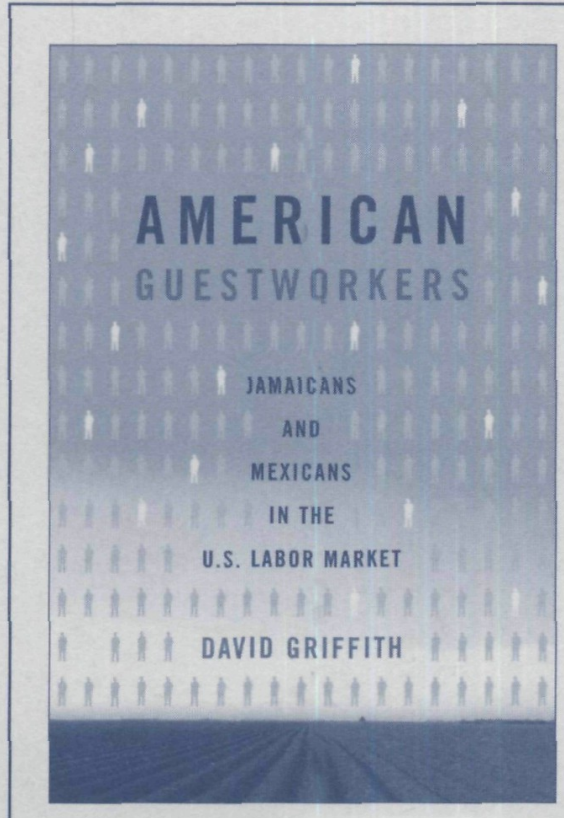

\section{AMERICAN GUESTWORKERS \\ JAMAICANS AND MEXICANS INTHE U. S. LABOR MARKET \\ David Griffith}

"Unlike the pundits who debate immigration policy within the context of border security or labor markets, David Griffith focuses on the history and evolution of the $\mathrm{H}-2$ program, examining the efficacy of actual guestworker policies and their effects on migrant workers. The value of American Guestworkers lies in the author's argument that local history can influence global processes. Throughout the book, Griffith proves his point by moving effortlessly between analysis of the local and national issues related to the H-2 program."

-Elżbieta M. Goździak, Georgetown University

The $\mathrm{H}-2$ program, originally based in Florida, is the longestrunning labor-importation program in the country. Over the course of a quarter-century of research, Griffith studied rural labor processes and their national and international effects. In this book, he examines the socioeconomic effects of the $\mathrm{H}-2$ program on both the areas where the laborers work and the areas they are from, and, taking a uniquely humanitarian stance, he considers the effects of the program on the laborers themselves.

232 pages | 4 maps | $\$ 55.00$ cloth Rural Studies Series

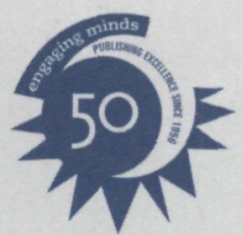

